\title{
ÚVODEM: KURIKULUM V PROMĚNÁCH ŠKOLY
}

Škola a její kurikulum ve všech možných podobách, variacích či modifikacích představuje důležitou oblast zájmu českého pedagogického výzkumu. Také v projektu LC 06046 Centrum základního výzkumu školního vzdělávání je současná česká škola a její kurikulum předmětem teoretické reflexe a výzkumu. V několika vzájemně provázaných tematických liniích se pozornost řešiteli projektu soustředí na školu jako učicí se organizaci, na faktory ovlivňující její reálnou podobu, na cíle, obsahy a procesy školního vzdělávání. Předkládané číslo Orbis scholae je výstupem vztahujícím se k dílčímu cíli 6 výše uvedeného projektu (viz Orbis scholae 1/2006), který směřruje k identifikování problémů souvisejících s tvorbou kurikula současné české školy.

Kurikulum $v$ širším pojetí jako veškerá zkušenost, kterou žáci získávají ve škole a vaktivitách se školou souvisejících, zejména prostřednictvím školního klimatu, patřík rozhodujícím fenoménům vzdělávacího procesu. Je tomu tak proto, že do kurikula se promítají obecné i specifické cíle výchovy, které jsou východiskem, orientačním ukazatelem i korektivem veškeré edukace. Kurikulum cíle naplňuje, proto je velmi důležité tento vztah ujasnit, a to jak smèrem $k$ filozofickým, antropologickým otázkám, tak téz vzhledem ke konkretizaci cílů $v$ podobě kompetencí, což ve své stati na základě analýzy školských dokumentù činí J. Skalková.

Od analýzy cílových kategorí je treba zaměrit pozornost na vlastní problematiku kurikula. J. Maňák se snaží vysledovat, z jakých zdrojủ se kurikulum utváří, a na základě modeli kurikula znázorňuje jeho vývoj, a to z hlediska systémového př́stupu. Z jiného pohledu D. Greger a K. Černý sledují, jaké důsledky pro tvorbu kurikula mají požadavky společnosti vědění. Dále jdou ve své analýze T. Janík a J. Slavík, kteří zkoumají vztah mezi oborem a od něho odvozeným vyučovacím předmětem. P. Knecht se zabývá didaktickou transformací, tj. problémem didaktického zprostředkování učiva žákům. Podobnou otázku si klade také K. Vlčková, která na ni hledá odpověd ve strategiích učení.

Následující stati se věnují konkrétnèjší problematice. R. Seebauerová analyzuje úroveñ absolventů rakouského školství a v souvislosti s tím seznamuje s problematikou tvorby vzdělávacích standardi̊ v Rakousku. J. Kratochvílová ukazuje, jak si vedou učitelé př́ tvorbě školního kurikula, a J. Beran, J. Mareš a S. Ježek představují výsledky empirického šetrení, které $v$ této problematice realizovali.

Č́slo doplnuují inspirativní zprávy a recenze vybrané zahraniční a domácí literatury. V̌sechny př́spèvky otevírají řadu problémů kurikula a vnášejí do této problematiky podněty pro dalši práci i návrhy na jejich řešení. Orbis scholae 1/2007 tak lze považovat za príspèvek $k$ probíhající reformě našeho školství. Kromě rešitelì projektu do čísla přispěli též externí odborníci. Jim všem a také recenzentům patří naše poděkování.

Josef Maňák a Tomáš Janík 